\title{
Experimental Investigation into Flow Behavior of Wood-Sediment-Water Mixture at a Grid Type of Open Check Dam
}

\author{
Haruyuki HASHIMOTO $^{1}$, Kyosuke HASHIMURA ${ }^{2}$, Hiroyuki NAGANO ${ }^{3}$ \\ and Farouk MARICAR ${ }^{4}$ \\ ${ }^{1}$ Dept. of Civil Engineering, Kyushu University (744 Motooka, Nishi-Ku, Fukuoka 819-0395, Japan) \\ E-mail: hasimoto@civil.kyushu-u.ac.jp \\ 2 JR Kyushu Railway Company (Hakata-eki Mae, Hakata-ku, Fukuoka 812-8566, Japan) \\ 3 Dept. of Civil Engineering, Tokyo University of Science (2641 Yamasaki, Noda, Chiba Prefecture 278-8510, Japan) \\ 4 Dept. of Civil Engineering, Hasanuddin University (Tamalanrea, Makassar 90245, Indonesia)
}

\begin{abstract}
Laboratory flume experiments showed the different behavior of sediment grains and wood pieces in debris flows (wood-sediment-water mixture flows) at an open check dam model. In the experiments, the debris flows were caused by putting some wood pieces on the initial movable bed and dropping the other wood pieces on the surface of the subsequent flow part. This condition resulted in the concentration of the former pieces at the flow front and the latter pieces on the subsequent flow surface. The latter pieces trapped in the check dam model were piled up on the former pieces trapped in the check dam. The sediment followed the pieces accumulating at the flow front. At the same time, sediment deposition was caused behind the trapped wood pieces.
\end{abstract}

Key words: open check dam, debris flow, woody debris, driftwood, wood-sediment-water mixture

\section{INTRODUCTION}

Hofu City, Japan was hit by heavy rain on July 21, 2009. This resulted in debris flows with a large amount of wood in the mountain rivers [e.g., Maricar et al., 2011]. During this event, the open check dams in the Hachimandani river trapped wood pieces in their opening and deposited much sediment behind the trapped wood pieces (Fig. 1).

The open check dams allow finer sediment to pass through at lower discharge and coarser sediment to be trapped at higher discharge such as debris flows. This type can be subdivided into slit-check dams, beam-check dams and grid-check dams. The viewpoint of environments makes the open type become preferable to the closed type. Therefore, an estimate of their appropriate opening becomes a problem [e.g., Ashida and Takahashi, 1980; Ashida et al., 1987; Mizuyama et al., 1988; Ishikawa et al., 1989; Armanini and Larcher, 2001]. Designing the open check dams requires knowledge of the dynamics of wood-sediment-water mixture flows at open check dams. However, little is known about their behavior at open check dams.

There are some previous works which investigated the effect of open check dams on debris flow containing wood pieces [Katatani and Yamada, 2006; Shibuya et al., 2009]. They examined the effects of open check dams from the viewpoint of sediment and wood control. Shibuya et al. [2009] treated grid type, and Katatani and Yamada [2006] dealt with slit type. However, little is known about the quantitative method of estimating the efficiency of these open check dams. Furthermore, there are less previous works regarding the effect of beam-check dams on debris flow containing wood.

Maricar et al. [2012] examined the trap efficiency of beam-check dams for wood-sediment-water mixture in the laboratory flume. In the experiments, they produced the wood-sediment-water mixture flow by placing wood pieces on the initial movable bed. This method made wood pieces concentrated in the flow front part and not in the subsequent flow part. Supply of wood pieces in the subsequent flow was needed in 


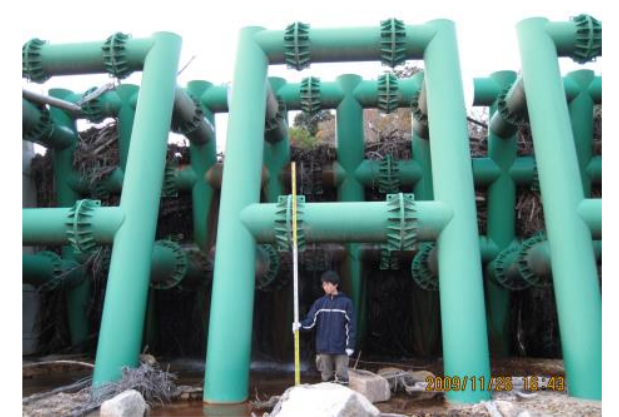

Fig. 1 The open check dam in the Hachimandani River in Hofu City, Japan.

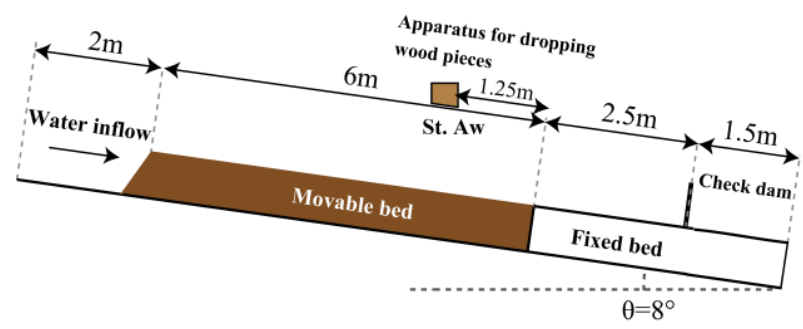

Fig.2 Elevational view of the laboratory flume.

Table 1 Characteristics of bed sediment and wood pieces. $\left(d_{50}\right.$ = diameter of sediment grains, $D=$ diameter of wood pieces and $L=$ length of wood pieces)

\begin{tabular}{|c|c|c|c|}
\hline Material & $\begin{array}{c}\text { Specific } \\
\text { gravity }\end{array}$ & $\begin{array}{c}\mathrm{d}_{50} \text { or D } \\
(\mathrm{mm})\end{array}$ & $\begin{array}{c}\text { Piece } \\
\text { length } \\
\mathrm{L}(\mathrm{cm})\end{array}$ \\
\hline Bed sediment & 2.65 & 3.6 & \\
\hline Wood model 1 & 0.76 & 2 & 7,10 \\
\hline Wood model 2 & 0.68 & 3 & 7,10 \\
\hline Wood model 3 & 0.66 & 4.1 & 7,10 \\
\hline Wood model 4 & 0.65 & 5.2 & $5.25,7,10$ \\
\hline
\end{tabular}

the experiments. The improved

supply method of wood pieces was proposed by Hashimura et al.[2013]. They put some wood pieces on the initial movable bed and dropped the other wood pieces on the surface of the subsequent flow in the laboratory flume experiments. They examined behavior of the mixture flow at a beam-check dam with an improved mixture production method.

The present study is an extension of the works of Maricar et al. [2012] and Hashimura et al. [2013]. By using the improved method of the wood supply, we investigate the behavior of wood and sediment in wood-sediment-water mixture flow at a grid-check dam as an open type.

\section{EXERIMENTAL METHOD}

Experiments were conducted with a laboratory flume. A rectangular flume was used in the experiments; it was $12 \mathrm{~m}$ long, $30 \mathrm{~cm}$ wide, and

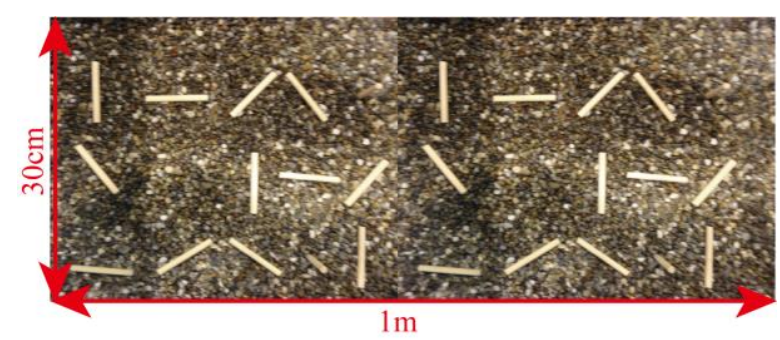

Fig. 3 Wood pieces placed on the initial movable bed.

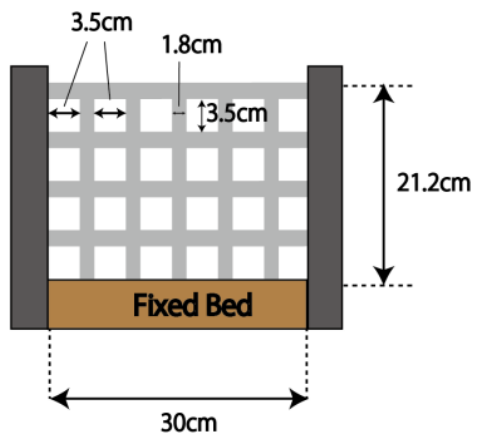

Fig. 4 Dimension of the open check dam model. (Front view of the model)

$32.8 \mathrm{~cm}$ high with smooth glass on the both lateral sides. A schematic diagram of this flume is shown in Fig. 2. The flume bed was composed of movable and fixed parts. The bed sediment was placed on the movable bed part and the check dam model was set on the fixed bed part. A square shaped box $30 \mathrm{~cm}$ wide and $36 \mathrm{~cm}$ long was installed at Station $A_{w}$ as an apparatus for dropping wood pieces on the flow surface.

Table 1 gives the characteristics of the bed material and wood models. The homogeneous sediment grains were used as the movable bed material. Their specific gravity was $\sigma / \rho=2.65$, where $\sigma=$ grain density and $\rho=$ water density. The representative diameter of the sediment grains was $\mathrm{d}_{50}=3.6 \mathrm{~mm}$.

Four kinds of wooden cylinder were used as the wood models; their diameter was $D=2.0 \mathrm{~mm}, 3.0$ $\mathrm{mm}, 4.1 \mathrm{~mm}$ and $5.2 \mathrm{~mm}$, respectively. Their length was set equal to $L=5.25 \mathrm{~cm}, 7 \mathrm{~cm}$ and $10 \mathrm{~cm}$. These scales were based on the field investigation of Maricar et al. [2011]. The length and diameter satisfy the condition of $L>D$. Their specific gravity was $\sigma_{w} / \rho=0.65 \sim 0.76$, where $\sigma_{w}=$ wood density.

We adopted the three different methods for putting wood pieces into the flow. For convenience, one is termed 'Method A', the second is termed 'Method B' and the third is 'Method $(\mathrm{A}+\mathrm{B})$ '. In 'Method A', we placed the wood model pieces of equal length and diameter in their different 


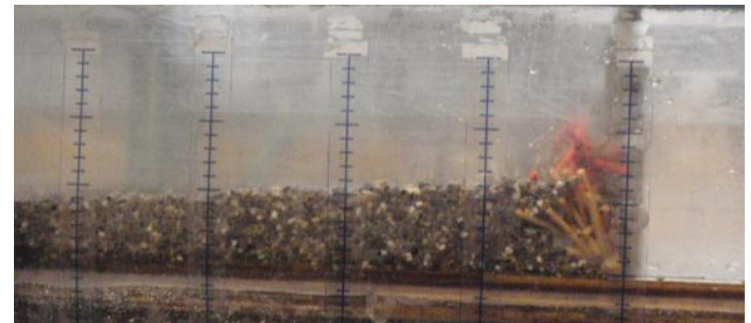

Fig. 5 Sediment and wood deposition at the check dam (View from the right-hand side of the flume).

Table 2 Experimental conditions.

\begin{tabular}{|c|c|c|c|c|c|c|c|}
\hline Run No. & $l_{0}(\mathrm{~cm})$ & $\begin{array}{l}\text { Piece length } \\
L(\mathrm{~cm})\end{array}$ & $\begin{array}{c}\text { Piece Diameter } \\
D(\mathrm{~mm})\end{array}$ & $N$ & $N_{d}$ & $\begin{array}{c}\text { Wood } \\
\text { supply } \\
\text { method }\end{array}$ & $l_{0} / L$ \\
\hline 1 & 3.5 & 5.25 & 5.2 & 120 & & A & 0.67 \\
\hline 2 & 3.5 & 5.25 & 5.2 & 60 & 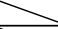 & A & 0.67 \\
\hline 3 & 3.5 & 5.25 & 5.2 & 30 & 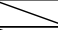 & $\mathbf{A}$ & 0.67 \\
\hline 4 & 3.5 & 10 & 5.2 & 180 & 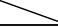 & A & 0.35 \\
\hline 5 & 3.5 & 10 & 5.2 & 120 & $x$ & $\mathbf{A}$ & 0.35 \\
\hline 6 & 3.5 & 10 & 5.2 & 60 & $x$ & $\mathbf{A}$ & 0.35 \\
\hline 7 & 3.5 & 7 & 5.2 & 180 & 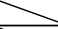 & A & 0.50 \\
\hline 8 & 3.5 & 7 & 5.2 & 120 & $x$ & $\mathbf{A}$ & 0.50 \\
\hline 9 & 3.5 & 7 & 5.2 & 60 & $>$ & $\mathbf{A}$ & 0.50 \\
\hline 10 & 3.5 & 5.25 & 5.2 & 180 & $x$ & $\mathbf{A}$ & 0.67 \\
\hline 11 & 3.5 & 5.25 & 5.2 & 120 & $>$ & $\mathbf{A}$ & 0.67 \\
\hline 12 & 3.5 & 5.25 & 5.2 & 30 & $>$ & A & 0.67 \\
\hline 13 & 3.5 & 7 & 5.2 & 150 & 90 & $\mathbf{A}+\mathbf{B}$ & 0.50 \\
\hline 14 & 3.5 & 7 & 4.1 & 180 & 90 & $\mathbf{A}+\mathbf{B}$ & 0.50 \\
\hline 15 & 3.5 & 7 & 3 & 180 & 90 & $\mathbf{A}+\mathbf{B}$ & 0.50 \\
\hline 16 & 3.5 & 7 & 5.2 & 180 & 90 & $\mathbf{A}+\mathbf{B}$ & 0.50 \\
\hline 17 & 3.5 & 7 & 2 & 180 & 90 & $\mathbf{A}+\mathbf{B}$ & 0.50 \\
\hline 18 & 3.5 & 7 & 4.1 & 120 & 90 & $\mathbf{A}+\mathbf{B}$ & 0.50 \\
\hline 19 & 3.5 & 7 & 4.1 & 0 & 120 & B & 0.50 \\
\hline
\end{tabular}

directions on the initial movable bed (Fig. 3). Number density of the pieces was 1 piece/(10 $\mathrm{cm} \times 10 \mathrm{~cm})$. In 'Method B', we dropped the wood model pieces on the flow surface at Station $A_{w}$. Therefore in 'Method (A + B)', we placed the wood model pieces on the initial bed and also dropped the wood model pieces on the flow surface at Station $A_{w}$. This instant release of the wood pieces on the flow surface was modelled after the woody debris inflowed by overland flow on valley slopes and riverside erosion.

A grid type was used as the open check dam model (Fig. 4).

The stainless tubes with the diameter of $18 \mathrm{~mm}$ were used for the grid-type of open check dam model (Fig. 4). The reduced size of the prototype was $1 / 50$; the prototype is the grid type of open check dam in the Hachimandani River, Hofu City, Japan (Fig. 1). The opening size $l_{o}$ of the check dam model was $l_{o}=3.5 \mathrm{~cm}$.

Video cameras were installed on the top and right-hand side of the flume to record the behavior of wood model pieces and sediment grains.

The flume was set at the slope angle of $8^{\circ}$.

The procedure in the experiments of 'Method $(\mathrm{A}+\mathrm{B})^{\prime}$ can be explained as follows:

Prior to the start of the tests, the sediment bed was saturated with seepage water and the wood model pieces were put on the initial movable bed.

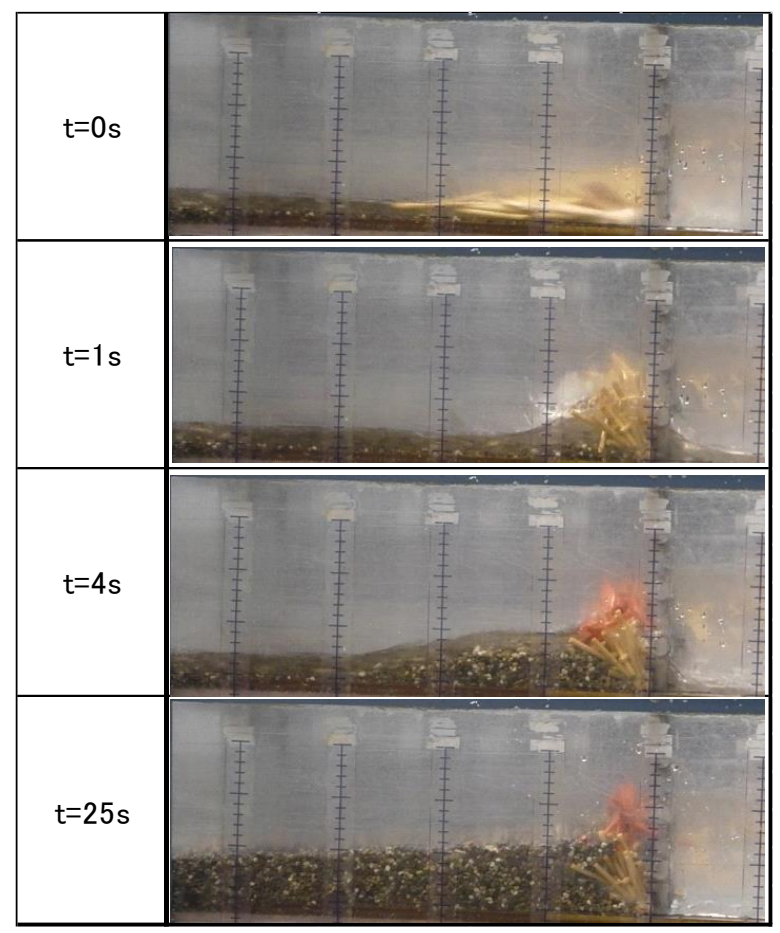

Fig. 6 Time change in flow situation after the arrival of flow front at the check dam (View from the right-hand side of the flume).

The mixture flow of wood, sediment and water was triggered by the quick water inflow $(q=100$ $\mathrm{cm}^{2} / \mathrm{s}$ )from the upstream end and then moved downstream along the flume bed. Most of the wood model pieces on the initial bed accumulated at the flow front and then arrived fastest at the check dam. Wood model pieces painted red were dropped on the flow surface at Station $A_{w}$ at the same time as the arrival of the flow front at the check dam. Therefore, the red wood pieces followed the wood pieces without red color at the check dam. Some amount of the wood and sediment were trapped in the check dam and the other passed through it. Figure $\mathbf{5}$ is a photo of situation of wood and sediment trapped in the check dam.

Table 2 describes the wood conditions for the experiment. Wood pieces were put on the initial movable bed for Run 1 to 18 , and no wood pieces on the initial bed for Run 19. Red wood pieces were dropped on the flow surface for Run 13 to 19. In this table, ' $N$ ' is the number of wood pieces placed on the initial movable bed and ' $N_{d}$ ' is the number of wood pieces dropped on the flow surface at Station $A_{w}$. The duration time of each experimental run was around 20 seconds from the arrival of flow front at the check dam. After stopping the water inflow, we counted wood pieces with and without red color, and measured the weight of sediment stopping and passing at the check dam. The sediment bed 


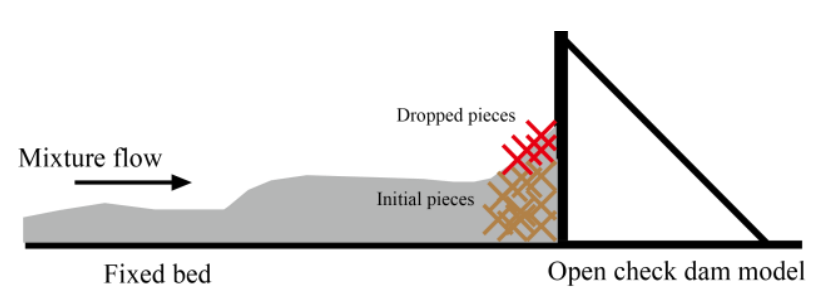

Fig.7 Schematic figure of wood and sediment deposition at the check dam.

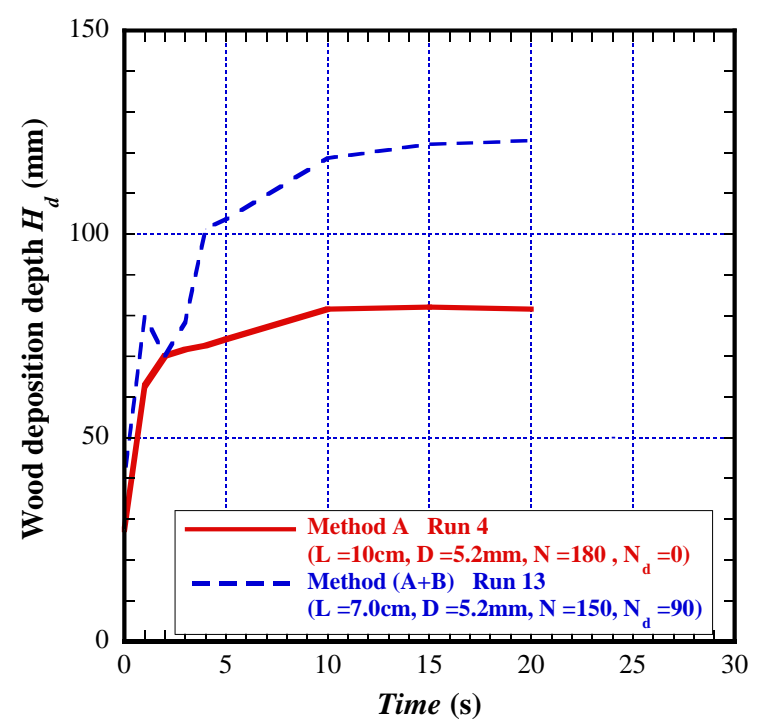

Fig. 8 Time variation in accumulation depth of wood pieces trapped by the check dam.

elevation behind the check dam was also measured by the point gage.

\section{EXPERIMENTAL RESULTS AND DISCUSSION}

\subsection{Behavior of wood and sediment at the open check dam model}

The flow behavior of wood-sediment-water mixture in the flume experiment is shown in Fig. 6.

The wood pieces on the initial movable bed were concentrated at the flow front during their movement and then arrived fastest at the check dam. After the arrival of the flow front at the check dam, the sediment followed the pieces accumulating at the flow front. Moving sediment pushed the trapped pieces against the check dam, pressed them and formed their complicated mesh structure. At the same time, sediment deposition was caused behind the trapped wood pieces. On the other hand, the red wood pieces dropped on the flow surface began to arrive at the check dam in around 3 seconds after the arrival of the flow front at the check dam. The red pieces trapped in the check dam model were piled up on the initial pieces trapped in the check dam.

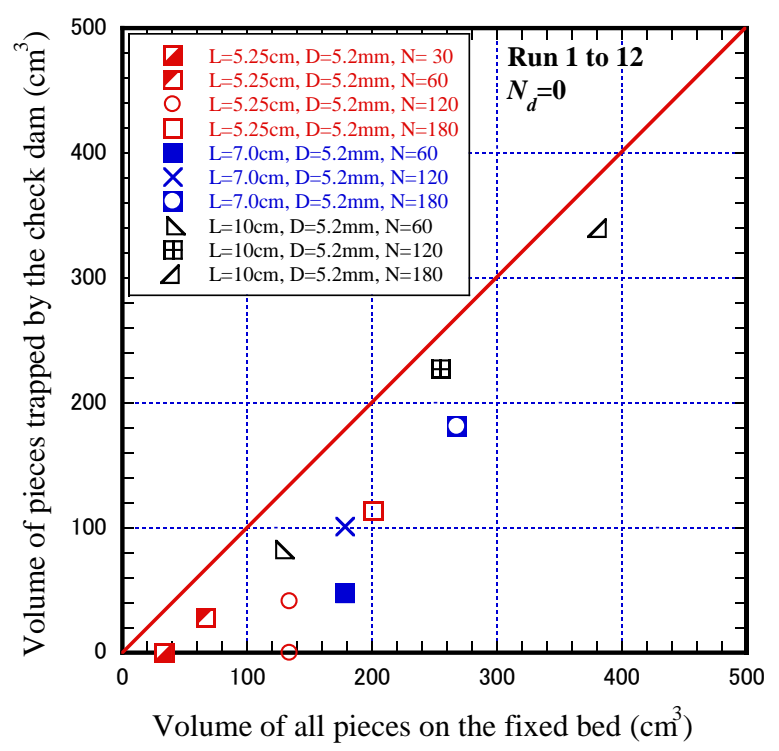

Fig. 9 Volume of pieces trapped by the check dam versus that of all pieces on the fixed bed.

This situation is schematically shown in Fig. 7.

The trapped red pieces caused an increase in accumulation depth of wood pieces at the open check dam model. The change in deposition depth of wood pieces is depicted in Fig. 8. The solid line shows the case in 'Method $A$ ' and the broken line indicates the case in 'Method $(\mathrm{A}+\mathrm{B})$ '.

In the experiment of 'Method A', the arrival of the flow front at the open check dam model caused a rapid increase in wood deposition depth. The wood deposition depth shows $z=7 \mathrm{~cm}$. Afterward almost same deposition depth was maintained.

In the experiment of 'Method $(\mathrm{A}+\mathrm{B})$ ', on the other hand, the arrival of the red pieces at the open check dam model yielded a more increase in wood deposition depth; the red pieces were dropped on the flow surface in about 3 seconds after the arrival of flow front at the open check dam model.

\subsection{Trap efficiency of the open check dam model}

The experiments show that the trapped wood pieces formed a kind of the mesh structure at the open check dam model and deposited sediment grains and red wood pieces from the subsequent flow. In this section, first, we examine the dependence of the wood pieces trapped in the check dam on its number and volume at the stationary, moving and trapping stages. Finally, we investigate the relationship between deposited sediment grains and trapped wood pieces.

Figure 9 expresses the relationship between the volume of wood model pieces trapped in the check dam model and that of all the pieces moving on the fixed bed. The solid line indicates that the volume of pieces trapped in the check dam is same as that of 


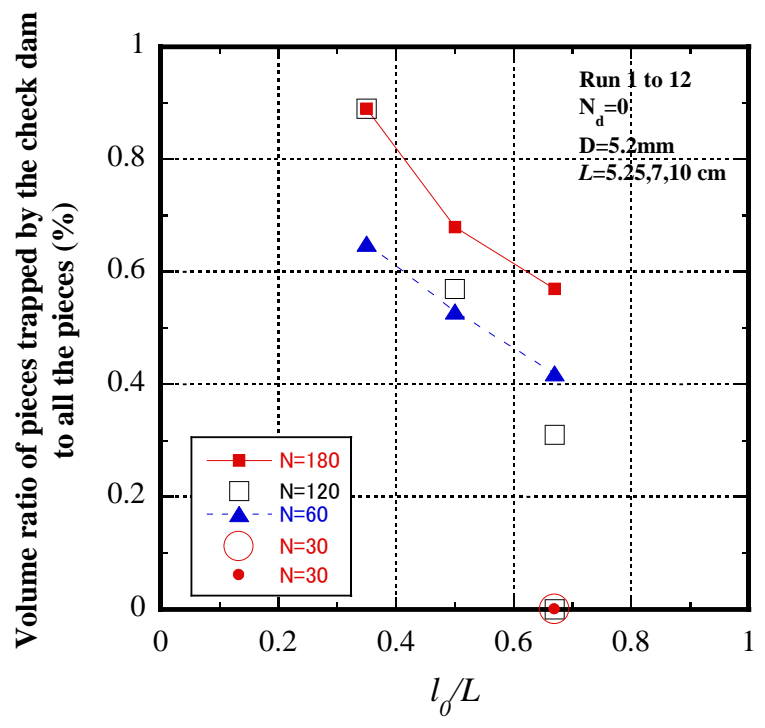

Fig. 10 Volume ratio of pieces trapped by the check dam to all the pieces versus $l_{o} / L$.

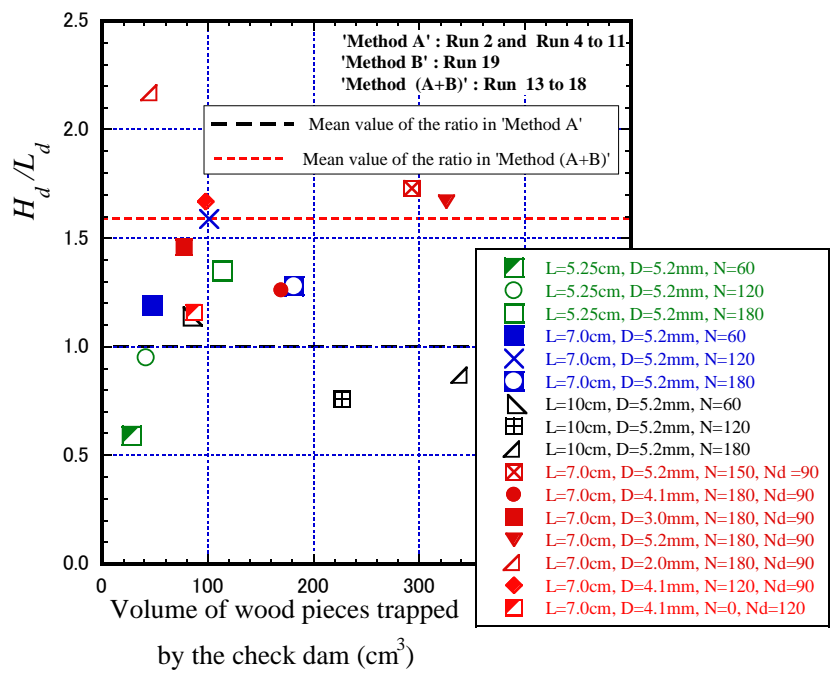

Fig. 11 Ratio of accumulation depth to length of trapped pieces versus volume of pieces trapped by the check dam.

all the pieces moving from the upstream bed part. From Fig. 9, it is found that trapping the pieces in the open check dam requires sufficient volume of the pieces moving from the upstream bed part.

Figure 10 indicates volume ratio of trapped the wood pieces to the all pieces. Some scatter of the data is noted at the region of $l_{o} / L=0.67$. It is found that the volume ratio of the trapped pieces to all the pieces decreases with the ratio $l_{o} / L$ and also becomes smaller rapidly with a decrease in the number of all the pieces.

This relationship is almost same as that in the beam-check dam [Maricar et al., 2012].

The length scale and structure of accumulation of the trapped wood pieces become important for sediment deposition from the subsequent debris flow. The ratio of accumulation depth to length, Fig.

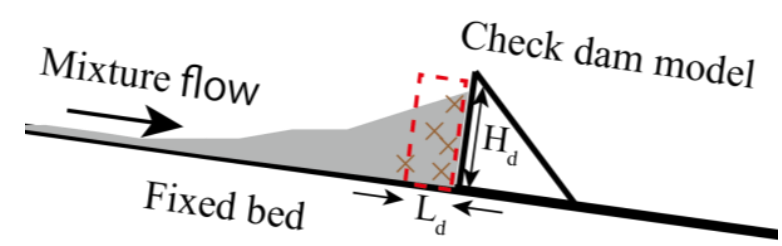

12 Definition of accumulation depth $H_{d}$ and length $L_{d}$ of wood pieces trapped by the check dam.

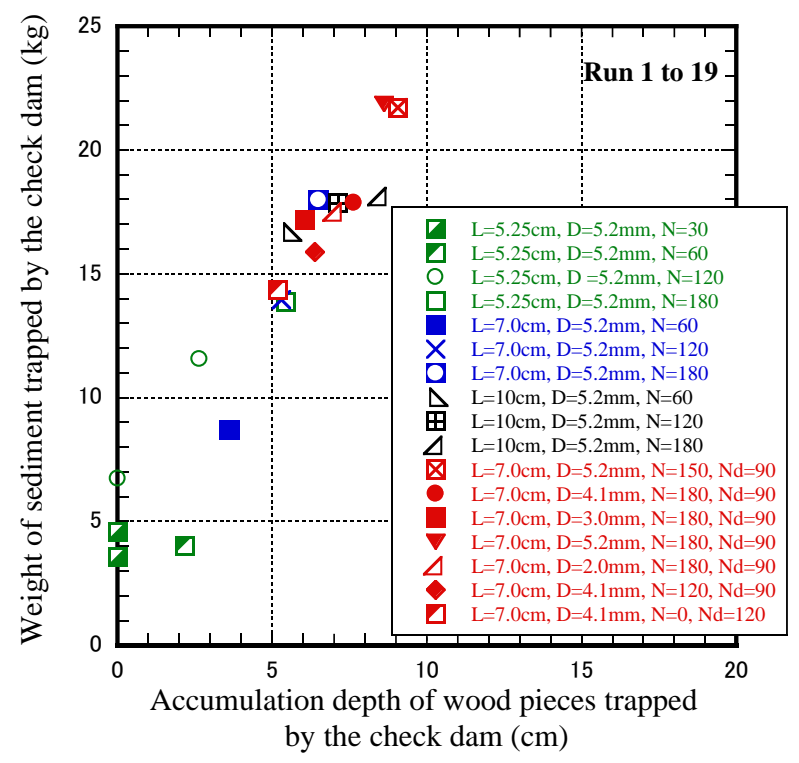

Fig. 13 Weight of sediment trapped by the check dam versus accumulation depth of pieces trapped by the check dam.

$H_{d} / L_{d}$, is investigated in Fig. 11. Here, measured accumulation depth $H_{d}$ and length $L_{d}$ were according to the definition in Fig. 12 from the video. Except the case of a small number of pieces, the ratio ranges in the value from 1.0 to 1.6.

We can see that the accumulation depth of trapped pieces extremely affects sediment deposition from the subsequent flow, as shown in Fig. 13. We can see a linear relationship between the weight of sediment deposited behind the trapped pieces and their accumulation depth.

\section{CONCLUSIONS}

The experimental investigation into the flow behavior of wood-sediment-water mixture at the grid type of open check dam model was carried out. The results obtained in this study are as follows:

1. Placing wood pieces on the initial movable bed and dropping red wood pieces on the flow surface yielded wood-sediment-water mixture flow. Most of the wood pieces on the initial movable bed were concentrated in the flow front part during their movement and some of them 
were trapped in the open check dam model. All of the red wood pieces in the subsequent flow arrived at the check dam model and some of them were trapped in the check dam model. The red pieces trapped in the check dam model were piled up on the initial pieces trapped by the check dam model.

2. Trapping wood pieces in the open-check dam model requires their sufficient number and volume.

3. A large number of wood model pieces result in significant sediment deposition behind the trapped pieces. Especially, the accumulation depth of trapped pieces determines sediment deposition from the subsequent debris flow. A linear relationship between weight of sediment deposited behind the trapped pieces and the accumulation depth of the trapped pieces can be found.

4. The length scale and structure of accumulation of the trapped wood pieces become important for sediment deposition from the subsequent mixture flow. The investigation into the ratio of accumulation depth to length of trapped pieces shows that the ratio ranges in the value from 1.1 to 1.6 except the case of a small number of pieces.

\section{REFERENCES}

Armanini, A. and Larcher, M. (2001): Rational criterion for designing opening of slit-check dam, Journal of Hydraulic Engineering, Vol. 127, No. 2, pp. 94-104.

Ashida, K. and Takahashi, T. (1980): Study on debris flow control- hydraulic function of grid type open dam-, Annuals of Disaster Prev. Res. Inst., Kyoto Univ., No. 23B-2, pp. 433-441 (in Japanese with English abstract).

Ashida, K., Egashira, S., Kurita, M. and Aramaki, H. (1987):
Debris flow control by grid dams, Annuals of Disaster Prev. Res. Inst., Kyoto Univ., No. 30B-2, pp. 441-456 (in Japanese with English abstract).

Hashimura, K., Hashimoto, H., Ikematsu, S., Rusyda, M.I. and Miyoshi, T. (2013): Depositional process of wood-sediment-water mixture flows at an open type of check dam, Proceedings of 12th International Symposium on River Sedimentaion, CD-Rom.

Ishikawa, Y., Mizuyama, T. and Fukuzawa, M. (1989): Trap efficiency for floating logs by sediment control dams and floating log trap booms, Civil Engineering Journal, PWRI, Vol. 31, No. 9, pp. 41-47 (in Japanese).

Katatani, M. and Yamada, T. (2006): Study on new type slit sabo dam development for reduction of slit blockade by drift woods, Journal of the Japan Society of Erosion Control Engineering, Vol.59, No. 3, pp. 23-31 (in Japanese with English abstract).

Maricar, F., Hashimoto, H., Ikematsu, S. and Miyoshi, T. (2011): Effect of two successive check dams on debris flow deposition, Italian Journal of Engineering Geology and Environment, pp. 1073-1082.

Maricar, F., Hashimoto, H., Ikematsu, S., Miyoshi, T. and Nagano, H. (2012): Behaviour of wood-sediment-water mixture flows at open check dam, Proceedings of the 18th Congress of the Asia and Pacific Division of the International Association for Hydro-Environment Engineering and Research, CD-Rom.

Mizuyama, T., Ishikawa, Y. and Yajima, S. (1988): Trap efficiency for floating logs by permeable sediment control dams, Civil Engineering Journal, PWRI, Vol. 30, No. 11, pp. 47-52 (in Japanese).

Shibuya, H., Haraki, D. and Katsuki, S. (2009): Experimental study on trap performance result of grid shape check dam debris flow with woody debris, Journal of the Japan Society of Erosion Control Engineering, Vol. 62, No. 1, pp. 66-73 (in Japanese with English abstract).

Received: 9 August, 2015

Accepted: 2 March, 2016 